\title{
DISCOVER THE POTENTIAL OF COMMUNITY-BASED TOURISM IN KUTU WETAN VILLAGE
}

\author{
Filda RAHMIATI ${ }^{1 *}$, Grace AMIN², Hanif Adinugroho WIDYANTO ${ }^{3}$ and Felix GOENADHI ${ }^{4}$ \\ ${ }^{1,2,3}$ Management Study Program, Faculty of Business, President University, Indonesia \\ ${ }^{4}$ Business Administration Study Program, Faculty of Business, President University, Indonesia \\ *filda.rahmiati@president.ac.id
}

\begin{abstract}
The COVID-19 pandemic and the strategy to Restart Tourism have become a turning point in increasing awareness of the role of sustainability in being more economically, socially, and environmentally sustainable. Tourism in rural areas offers significant recovery opportunities as travelers seek fewer crowds, open-air experiences, and local cultures. This study aims to see the potential of Kutu Wetan Village to be community-based tourism using the 4C (Conservation, Community, Culture, and Commerce) model. Qualitative data collection methods were carried out through in-depth interviews and participatory observations. This study is focusing on the Kutu Wetan Village, Jetis District, Ponorogo Regency, East Java. The result of this study affirms that there is a potential for Kutu Wetan Village to be a community-based tourism village. The community is happy to work together to preserve the existing culture by regularly cleaning the Suru Kubeng meditation location, regularly performing Reog at events on important dates. The beauty of the rice field available is a great potential for tourism development. However, Kutu Wetan Village still has a lot to prepare to create Community-based tourism. A tourism village should also implement tourism value chain activities (TVCA) for competitive advantage creation. This study also provides several recommendations for successfully creating community-based tourism based on World Tourism Organization (UNWTO) (2021).
\end{abstract}

Keywords: Community-Based Tourism, Cultural, Commerce, Conservation, Community, Pandemic Tourism

\section{BACKGROUND}

The Former Minister of Tourism and Creative Economy of the Republic of Indonesia, Wishnutama, said that tourism was the first most affected sector by the COVID-19 pandemic. Closure of city and state boundaries results in a decrease in tourism competitiveness (Kuswaraharja, 2020). Losses in the form of a reduction in international tourist arrivals by 64.11 percent (Rahayu, 2020) and million jobs in the tourism sector at risk (UNWTO, 2020). Moreover, lost revenues severely impact communities, heritage sites, and cultural events while weakening destinations' competitiveness and market differentiation. On the other hand, tourism in rural areas offers meaningful recovery opportunities as travelers seek fewer crowds, open-air experiences, and local cultures. The global pause of travel has created an opportunity to move away from unsustainable practices of the past towards more resilient, inclusive, and resource-efficient models that contribute to the Sustainable Development Goals (SDGs) (Halimatussadiah et al., 2020).

In response to this, the Indonesian government has set a strategy for handling the tourism crisis due to the pandemic according to the United Nations World Tourism Organization (UNWTO) standard, namely "Restart Tourism" (Aziz et al., 2020). The COVID-19 pandemic and the strategy to Restart Tourism have become a turning point in increasing awareness of the role of sustainability. This is the right time to move towards a tourism model that is more economically, socially, and environmentally sustainable (Sustainable Tourism Model) (UNWTO, 2020). The sustainability of tourism is also strengthened through community-based tourism (Sasongko et al., 2019; Singgalen et al., 2019; Thetsane, 2019). By empowering the community as tourism actors, tourism development will be improved. If all components are appropriately considered, the tourist travel experience will be more memorable, and the tourism sector's recovery will be faster (World Travel \& Tourism Council, 2020). The 4C (Conservation, Community, Culture, and Commerce)model is a concrete way of conceptualizing sustainability where each $\mathrm{C}$ supports the other. Conservation (conservation) has a positive impact on the community (community), trade (commerce) also helps the development of culture (culture). Culture can develop with community efforts. A business that does not harm culture, community, and nature conservation makes the tourist experience more meaningful (The Long Run, 2020).

One of the famous tourist attractions in rural areas is Reog Ponorogo that has become a cultural heritage. Reog Ponorogo is one of the traditional performing arts that has captured the attention of the public on a local, national, and international scale, and it is one of the cultural arts with the potential to become a national cultural identity (Afiati, 2018) owned by every Village in Ponorogo Regency. Ponorogo Regency is an agricultural area located in East Java Province. As a farming area, the culture that has developed a lot is the people's traditional culture. The existing culture, including the arts in it, has various functions in society. Besides Reog attractions, it also has many tourist attractions such as a site (Situs), a strong cultural attraction potential (Verian, 2020). Although it has great potential, tourism development in Ponorogo Regency is currently still not optimal. Various essential components for developing tourist villages such as accommodation, tourist activity attraction products offered, accessibility, and promotional strategies are still minimal (Ismail \& Rohman, 2019). The tourism revenue contribution to East Java Province has not contributed more than $20 \%$ to Indonesia's movement of domestic and foreign tourists. Some of the challenges faced include the quality of tourism products was not yet 
optimal, a lack of human resource professionals, a lack of tourism actors who are professionally certified, and a need to improve the quality of tourism services (Department of Culture and Tourism of East Java Province, 2018). Thus, the development of a tourism village will be appropriate to enhance tourism in the Ponorogo Regency. This study will focus on Kutu Wetan Village, which has not been appointed to be a tourism village, regardless of tourist attractions in the Village, by emphasizing community-based tourism. Based on the above mentioned, this study aims to discover the potential of Community-based tourism in Kutu Wetan Village, Ponorogo Regency, East Java Province.

\section{Community-based Tourism}

Community-based tourism can be defined as the utilization of local potential in the tourism sector. By empowering the community and asking for their participation as tourism actors, tourism development will be higher (Singgalen et al., 2019). The idea of communitybased tourism (CBT) is a new model in tourism development, more related to the impact of tourism on local communities and environmental resources. Communitybased tourism uses tourism as a vehicle to strengthen the capacity of rural/local organizations and communities. This method is positively correlated with increased people's income (Sasongko et al., 2019).

Research on community-based tourism has been carried out by Pamulardi (2006). As initial capital in developing environmentally friendly agro-tourism, it is necessary to cooperate with entrepreneurs who have succeeded in developing tourist villages. The management is carried out by partnership management, with principles based on community participation, cooperation, and open management. In addition, it is essential to have support from the local community for the development of environmentally friendly tourism villages.

The form of community participation in the development of tourist villages can be in the form of the involvement in the development of ideas and input, labor in the form of volunteer work, participation in property in the form of goods given by the community when there are activities, participation in skills of making wayang, batik, and pottery crafts, lastly social participation in the form of caring activities (Alfiani, 2016). This impacts increasing visits to Tourism Villages, preserving the culture in tourist villages, utilizing existing studios as potential tourist villages that affect additional income and create jobs for the community.

\section{C (Conservation, Community, Culture, and Commerce)}

Travel businesses should be able to place the balance of 4Cs (Conservation, Community, Culture, and Commerce), namely Conservation, Community, Culture, and Commerce, at the core of everything. The $4 \mathrm{Cs}$ are a concrete way to conceptualize sustainability, which is the only way for businesses to survive. Each C supports the other through a holistic lens. It is vital to ensure that conservation benefits the community. Trade helps cultural development, culture is seen as part of the community, and the implementation of trade systems is appropriate not to harm culture, community, and conservation (The Long Run, 2020). Individuals play a role in supporting biodiversity, climate, and social protection and recognizing this, exploring how to improve a more meaningful tourist experience, including health and safety, and innovating new products to drive a sustainable mission. Currently, conservation, the tourism industry, and the community are no longer underestimated but must be the main supporting factors.

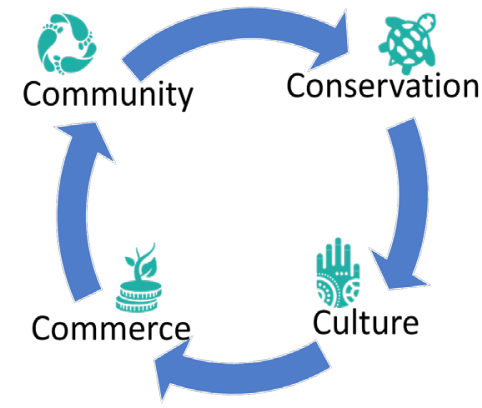

Figure 1. The 4Cs framework

Source: The Long Run (2020)

\section{Cultural Heritage}

Ariyanto (2014) explained that the preservation and management of cultural heritage benefit national development, such as the benefit of academic, economic, and ideological interests. The educational use of preserving and managing cultural heritage is that cultural heritage is an object of research for various scientific disciplines. As an object of study, cultural heritage has values that need to be revealed with past cultural values. The economic benefit of managing cultural heritage as a tourist attraction is to improve the community's welfare and the government. The ideological benefits of collecting and preserving cultural heritage are because, as a result of past human works, cultural heritage contains noble values that are important for the development of Indonesian people. Therefore, the role of cultural heritage as a strengthening of national identity needs to be accompanied by efforts that can shape the character of people who have personalities according to their cultural roots. One of these efforts is to promote cultural heritage values through education.

One of the cultural heritage discussed in this study is Site (Situs). Kusmayadi (2018) stated that a site is defined as a place that contains artifacts, features, and/or ecofacts, a material cultural heritage in the form of Cultural Conservation Objects, Cultural Conservation Buildings, Cultural Conservation Structures, Cultural Conservation Sites, and Cultural Conservation areas on land and/or in water whose existence needs to be preserved because it has an important value for the history of science, education, religion and/or culture through the determination process. The site located in Kutu Wetan Village, Jetis District, Ponorogo Regency named Suru Kubeng, is part of the 
history of the existence of Ponorogo. Because Ki Demang Ketut Suryongalam used that place as a place to meditate, this place is the forerunner of Ponorogo, said the former regent of ponorogo, Ipong Muchlissoni (Marhaban, 2019).

Additionally, one of the regional arts that have become a cultural heritage is Reog. Reog is a native Indonesian culture that combines masks, theatre, music, and dance. Reog is thought to have been created around the 12th century. Reog is one of the many Indonesian cultures that are influenced by magical or supernatural elements. This is primarily influenced by the lives of the ancestors of the Indonesian people, who mostly lived in the past when it was the heyday of kingdoms, which of course, was influenced by things that smelled magical to survive in those days. The performing arts are very thick with mystical things. In the art of Reog Ponorogo, there are Islamic values that are not yet known to most people today. Local wisdom. In Reog, a tiger mask (Barongan / Cekathakan) is haunted and arrogant, decorated with bluish-green and shiny peacock feathers. The tiger mask symbolizes evil, and the peacock feather symbolizes virtue. This reminds us that every evil will be defeated by virtue showing human nature and the journey of human life in the world (Alfiati, 2018).

The famous Reog is from Ponorogo, which people usually called "Reog Ponorogo." Reog Ponorogo is one of the traditional performing arts works that has become the center of attention of the community, both locally, nationally, and internationally and is one of the works of cultural art that has the power to become an identity as a national culture. In the city of Ponorogo, reog is one of the elite performances which is usually only shown at large events \& certain events, such as the holding of the National Reog Festival (FRN), Mini Reog Festival (FRM), and the full moon reog (one Suro performance). Usually, Reog is performed when the people's party is in progress, and Reog is the peak performance most awaited by the public. The Reog show is usually performed in a city square because Reog involves many supporters of the event and a series of mandatory performances that must be achieved during a Reog show. The show involves dozens, each of which has its performance task (Saka, 2021). The function of reog performances as a means of entertainment and a medium for preserving distinctive arts is an educational medium for increasing tourists (Mala, 2020).

\section{METHOD}

The research method is based on Richards and Munsters (2010) book entitled "Cultural Tourism Research Method." Qualitative data collection methods were carried out using surveys, in-depth interviews, and participatory observations. This study is focusing on the Kutu Wetan Village, Jetis District, Ponorogo Regency, East Java. The Village was chosen because it is famous as an area that preserves culture, such as the Reog Ponorogo performance and the availability of Site (Suru Kubeng). This area also has a natural potential that is beautiful and clean of rice fields. Based on data collection made then answer the aim of this study of the potential of Community-Based Tourism in Kutu Wetan Village, Ponorogo Regency, East Java Province.

\section{RESULTS AND DISCUSSION}

Based on the data collection made, from observation, the interview also various secondary data collected. This study affirms that there is a potential for Kutu Wetan Village to be a community-based tourism village. In terms of village accessibility is good, roads leading to tourist access, sites are good enough. As shown in Figure 1b, the village community is happy to preserve the existing culture. One way is to clean the location of the Suru Kubeng meditation regularly. Another activity is preserving the Reog Ponorogo culture by performing it at events on important dates such as 1 Suro. In terms of nature conservation in the Village of Kutu Wetan, the natural beauty still maintained can be used as a tourist attraction with great potential. Nowadays, not many urban people can still enjoy the fresh air and village atmosphere and feel the beauty of playing and growing crops, such as planting rice in the fields (see Figure 1a). The souvenir shops are also available as this Village is also surrounded by several Islamic boarding schools in neighboring villages, the largest of which is the Gontor Islamic Boarding School. There are many students from various cities in Indonesia. Finally, through developing the Village to be communitybased tourism, it can bring about an increase in the economy of the Kutu Wetan village community and also, of course, have an impact on village income to the Village, introduce Kutu Wetan village to the broader community so that the village economy can be lifted. Thus, the $4 \mathrm{C}$ model of Conservation, Culture, Community, and Commerce can be carried out correctly through good coordination.

However, Kutu Wetan Village still has a lot to prepare to create Community-based tourism. Where in every tourism activity, tourism value chain activities (TVCA) must be fulfilled, including travel agents, transportation companies, lodging (homestay), unique souvenirs, and tour guides (Rahmiati, 2020), which able for competitive advantage creation. Starting from introducing Kutu Wetan village to the broader community, the availability of adequate transportation to the village location, the availability of lodging for tourists, as well as a qualified tour guide to provide explanations about existing tourist attractions, besides that, the availability of typical village souvenirs is important for tourists gives a memorable impression of the Village. Therefore, preparation to make it all work is crucial. Thus, the role of the village community in the creation of community-based tourism is important.

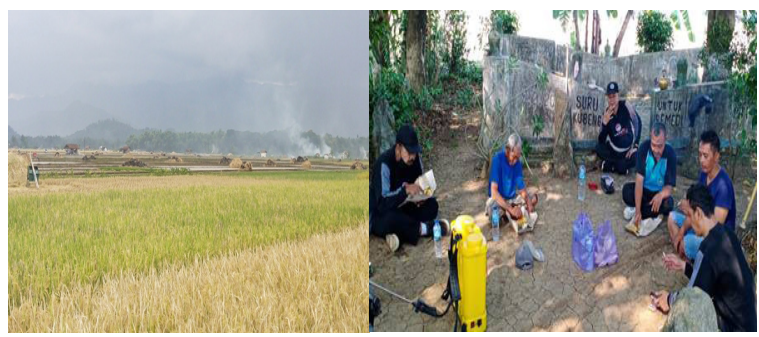

Figure 1. (a) Rice field, and (b) Location of Site, Suru Kubeng 


\section{CONCLUSION}

In preparing for restart tourism, community-based tourism is one of the practical steps in which tourists today are more interested in visiting natural and cultural tourism. Therefore, implementing the $4 \mathrm{C}$ model is expected to be a guide for preparing community-based tourism in Kutu Wetan Village. The shared values and close ties between tourism and culture stakeholders mean both sectors can work together to ensure inclusive access to heritage as countries worldwide recover from the pandemic. They are focusing on the responsible restart of cultural tourism. Based on the result, the Kutu Wetan Village can be built as community-based tourism. However, there is still a lot of homework to be prepared for this success. Thus, participatory governance structures and artists, creators, tourism and culture professionals, the private sector, and local communities are crucial.

There are several recommendations for the success of creating community-based tourism based on the World Tourism Organization (UNWTO) (2021), such as: (1) Reengage with local communities by targeting domestic travelers. Promotion strategy could be through electronic media, including television, online sites and social media, and visual communication media, including banners and billboards. (2) Strengthening the revival of urban and rural experiences by utilizing the community in the recovery, particularly women, youth. (3) Building a more resilient tourism and culture workforce through the digital transition by training and professional upskilling to new technologies and customer service adjustments to new health measures that require up-to-date skills. Digital upskilling of women, youth, indigenous peoples, and marginalized communities is urgently needed. (4) Fostering community-based tourism through living heritage by raising awareness of the important role of communities and cultural practitioners and their living heritage on the sustainable development of tourism. Ensure that communities and practitioners are the primary beneficiaries and have a leading role in tourism management. (5) Protecting nature is key to safeguarding culture by educating visitors to be respectful and mindful of both the natural and cultural values properties and protected areas they visit. This will help ensure responsible, low-impact tourism while enhancing the visitor experience.

\section{ACKNOWLDEGEMENT}

The study was funded by the Ministry of Education, Culture, Research, and Technology Directorate General of Higher Education, 2021. No. 003/SP2H/RT-JAMAK/ LL4/2021. And also supported by the Department of Research and Community Services, President University.

\section{REFERENCES}

Alfiani, F. (2016). Partisipasi Masyarakat Dalam Pengembangan Desa Wisata Grogol, Margodadi, Seyegan, Sleman, D.I. Yogyakarta. Skripsi. Fakultas
Dakwah dan Komunikasi, Universitas Islam Negeri Sunan Kalijaga.

Alfiati, A. (2018). "Relasi Nilai Agama Islam Dan Budaya Dalam Kesenian Reog Ponorogo". An-Nuha: Jurnal Kajian Islam, Pendidikan, Budaya Dan Sosial, Vo. 5 No. 2, pp.173-188.

Ariyanto, Y. B. (2014). "The Benefits of Preserving and Management of Cultural Conservation for the Interests of National Development." Proceedings of the Archaeological Seminar 2014.

Aziz, M. F., Handayani, S., \& Nasution, H. M. A. A. (2020). Telaah Yuridis Investasi Pemerintah Dalam Menyelamatkan UMKM Pariwisata Akibat Pandemi Covid-19. Jentera: Jurnal Hukum, 3(1), 202-215.

Department of Culture and Tourism of East Java Province (2018). Laporan Kinerja Instansi Pemerintah (LKjIP) tahun 2018. Retrieved from http:// disbudpar.jatimprov.go.id/.

Halimatussadiah, et al. (2020). "Thinking Ahead: Indonesia's Agenda on Sustainable Recovery from COVID-19 Pandemic". Institute for Economic and Social Research Faculty of Economics and Business, Universitas Indonesia (LPEM FEB UI) and Ministry of National Development Planning/ National Development Planning Agency (BAPPENAS).

Ismail, T. dan Rohman, F. (2019). "The Role of Attraction, Accessibility, Amenities, And Ancillary on Visitor Satisfaction and Visitor Attitudinal Loyalty of Gili Ketapang Beach." Jurnal Manajemen Teori dan Terapan Vol. 12, No. 2.

Kusmayadi, Y. (2018). "Pengembangan Potensi Wisata Situs Gandoang Wanasigra Untuk Meningkatkan Kesejahteraan Ekonomi Masyarakat Desa Wanasigra Kecamatan Sindangkasih Kabupaten Ciamis". Candrasangkala: Jurnal Pendidikan dan Sejarah, Vol. 4 No.1, pp.31-47.

Kuswaraharja,D.(2020,June2). Efek coronakewisata, izin khusus lion air, hotel yogya berguguran. Retrieved from Detik Travel: https://travel.detik.com/travelnews/d- 4997549/efek-corona-ke-wisata-izinkhusus-lion-air-hotel-yogya-berguguran.

Mala, D. K. (2020). "Pengelolaan pertunjukan reog dalam event bulan purnama di Kabupaten Ponorogo". SKRIPSI Mahasiswa UM.

Marhaban, M. (2019). "Bupati Ponorogo Ziarah ke Makam Bathoro Katong dan Petilasan Surukubeng”. Times Indonesia. From: https://www.timesindonesia.co.id/ $\mathrm{read} /$ news/227266/bupati-ponorogo-ziarah-kemakam-bathoro-katong-dan-petilasan-surukubeng. 
Pamulardi, B. (2006). Pengembangan Agrowisata Berwawasan Lingkungan (Studi Kasus Desa Wisata Tingkir, Salatiga). Doctoral dissertation, Program Pasca Sarjana, Universitas Diponegoro.

Rahayu, A. (2020, April 23). Siaran Pers: Enam Langkah Kemenparekraf di Masa Darurat COVID-19. Retrieved June 16, 2020, from Kemenkraf: https:// www.kemenparekraf.go.id/post/siaran-pers-enamlangkah-kemenparekraf-di-masadarurat- covid-19.

Rahmiati, F. (2020). "Meningkatkan Keunggulan Kompetitif Pariwisata Indonesia melalui Aktivitas Rantai Nilai Pariwisata". Bogor. PT. Filda Fikrindo

Richards, G. and Munsters, W. (2010). Cultural Tourism Research Methods. CABI. UK.

Saka (2021). "Reog Performance in various events." Interview, April 2021.

Sasongko, G., Trianggono, B., \& Wiloso, P. G. (2019). Development of Community-Based Tourism in Pinusan Kragilan, Pogalan Village, Magelang Regency, Central Java, Indonesia. Journal of Indonesian Tourism and Development Studies, 7(3), 156-165.

Singgalen, Y. A., Sasongko, G., \& Wiloso, P. G. (2019). Community participation in regional tourism development: a case study in North Halmahera Regency-Indonesia. Insights into Regional Development, 1(4), 318-333.
Tamara, D. S. Y.O.(2018). “Analisis Strategi Pengembangan Obyek Wisata Situs Jolotundo sebagai Obyek Wisata di Kawasan Peruntukan Pariwisata Budaya Kabupaten Mojokerto". Swara Bhumi, Vol. 5 No.5. pp. 9-17

The Long Run (2020). Conservation and community must come first for tourism to recover responsibly and build back better for people and the planet https:// www.oneplanetnetwork.org/tourism-responsiblerecovery-covid-19-the-long-run.

Thetsane, R.M (2019). "Local Community Participation in Tourism Development: The Case of Katse Village in Lesotho." Athens Journal of Tourism. Vol 6, No. 2. pp 123 - 140. https://doi.org/10.30958/ajt.6-2-4.

UNWTO. (2020). COVID-19: putting people first. Retrieved June 2, 2020, from UNWTO: https:// www.unwto.org/tourism-covid-19.

Verian, B. (2020) "Kendala bagi desa wisata di desa Kutu Wetan” Interview. October, 2020.

World Tourism Organization (2021), UNWTO Inclusive Recovery Guide-Sociocultural Impacts of Covid-19, Issue 2: Cultural Tourism, UNWTO, Madrid, DOI: https://doi.org/10.18111/9789284422579.

World Travel \& Tourism Council (2020). \#TogetherInTravel campaign to inspire the global tourism community. https://wttc.org/News-Article/ WTTC-launches-TogetherInTravelcampaign- toinspire-the-global-tourism-community. 